\title{
PRODUCERS' REACTION TO CLIMATE CHANGE IN THE FRUIT PRODUCTION SECTOR FROM THE POINT OF VIEW OF GROWERS
}

\section{Dóra Demeter}

\author{
Károly Róbert University College, Gyöngyös, Hungary
}

\begin{abstract}
Within the sector of fruit growing, climate change related tasks cover a rather wide range of activities. According to what is claimed by the literature, all decisions impacting the sector should be made conformably with climate change in order to advance an increase in yield security. This, regardless of the impacts of climate change, is also one of the key questions in fruit growing. Regarding protection against extreme weather events, in addition to technological and technical elements, the level of importance assumed by farmers for the above-mentioned protection techniques as well as the type and extent they intend to use in practice are also worth of studying. This ongoing research began in 2009 and focuses mainly on studying the opinions of fruit farmers making up the target group for this analysis. The questionnaire survey primarily intends to study their knowledge on the definition of climate change as reactivity to unfavourable weather events occurring in the growing. Additionally, we tried to get answers to the following questions: Do the studied human factors (age, educational level, sex etc.) of growers determine the extension of innovation of fruit production?
\end{abstract}

Keywords: climate change, fruit growing, protection, yield security; human factor

\section{Introduction}

Although the notion of climate change is familiar to almost everyone, the very meaning of this definition is known and conceived by significantly less. As extreme weather phenomena determine yield security, this fact is extremely important among those directly involved in food production. Based on the experiences obtained so far, fruiticulture in Hungary will not be basically impacted by the increase of temperature but the frequency of extreme weather events. Their frequency of occurrence will decisively influence the quantity and quality of fruits growable as well as result in the shrinking of production areas (Soltész et al., 2007). Due to scientific uncertainties, it is complicated to analyze the potential impacts of global climate change. And this is also the case as from the empirical results of social scientific studies, only the nature of relations various social groups have today to nature, physical environmental problems and the (mainly believed) impacts of the global climate change can be concluded. Taken society as a whole, exploring future interests is not only difficult as people are aware they should abandon their interests of today for their future interests but also as this future interest is rather difficult to enforce (Szirmai, 2009).

In our study, we research three types of technologies: integrated, organic and conventional.

Nowadays the most frequently applied environmentally-benign fruit management systems are integrated and organic production. However, integrated and organic fruit management systems demand different requirements. Integrated management system optimizes both environmental issues and economic profit by utilizing methods of conventional and organic production systems. Therefore, some chemical pesticides and fertilizers are allowed to be used in the integrated system (Sansavini, 1990).

Organic fruit growing programs address strictly environmental issues; and therefore, exclude synthetic pesticide and fertilizer inputs and use naturally derived products for plant protection and nutrient supply (Werner, 1997; Glover et al., 2000).

Both organic and integrated production systems strive towards sustainability by minimizing environmental degradation and improving soil quality, while maximizing productivity as well as economic returns (Reganold et al., 2001). Conventional fruit growing refer to the method of edible plants. This technology often uses fertilisers and pesticides which allow for higher yield, greater resistance, longevity, and generally greater mass.

Farmers involved in fructiculture, on the contrary to this general phenomenon, perceive that the implementation of this 'future interest' will determine yield security and by this, their profitableness as during production, they closely apprehend the negative impacts of extreme weather phenomena. It is important to emphasise that this current examination is a "situation report", therefore, it cannot describe the temporal changes of the explored phenomena. The study aims at providing a realistic view on the fruit-farmers' knowledge on climate change and on how technological elements, new technical solutions applicable to mitigate damage are used during production.

\section{Material and methods}

In this study, a questionnaire survey frequently applied in social scientific researches was used. This method bears a number of advantages as being relatively rapid, suitable for providing descriptive statistical studies on large assemblies and from the data obtained from the results of such surveys, secondary analyses can be simply conducted (Babbie, 2001). Secondary analyses were carried out following simple statistical studies evaluating and quantifying the basic features of the study sample. The growers who filled the questionnaire were selected with random simple sample.

Descriptive statistical methods applied were frequency test during which the variables' relative and cumulative distributions within a given topic were analysed and represented. For multiple answers, the analysis was conducted by applying frequency and crosstabs in accordance with the previously defined groups and sets of multiple answers.

The association between variables of nominal in type advancing our study of hypothesis was described by association measures. During the analysis, data were arranged to crosstabs, validity of causality associations assumed based on the arrangement of frequencies were proven by applying definitely a chi-square test. The level of significance was set on the conventional value $(p \leq 0.05)$. This study primarily intends to examine 
knowledge on the concept of climate change and reactivity to unfavourable weather phenomena occurring in nature among farmers. In addition to these, the research also aimed at obtaining qualitative and quantitative information required for the development of consultancy and research guidelines.

As the character of this study approaches social scientific research, it contains a number of uncertainty factors. Despite these, such a survey on opinions is necessary and relevant as respondents are not only actors of the society as a whole but in the meantime, they are also active 'participants' in agricultural production otherwise generating a significant level of environmental loading (obviously, global climate change is not only impacted by production itself but also by many other social mechanisms). They are polluters as well as the victims of the pollution and moreover, their exposition in relation to this global environmental problem is rather high.

Risk factors of climate change such as long arid periods, floods, storms, forest fires, discrepancies in drinking water supply, descent of ground water level, spreading of invasive weeds and dragged-in insects, a Mediterranean type conversion of living world, heat stress, allergies, haemal affections and increasing energy demand have become more and more obvious in recent years (Harnos-Csete, 2008). Such are the risk factors that members of the study's target group face probably the most frequently as well as for them, the occurrence of extreme weather phenomena represents a failure of the rather significant profit for them and even in many cases determining their sustenance (nearly all in the past 5 years frost in May occurred with the one in 2007 being especially crucial with the case being similar for drought damaging plantations on several occasions with the exception only being the past year).

The study was made in the year of 2009, the studied population consisted of the members of a fruit-grower marketing organization (Gyümölcsért Ltd.), that organizes growing and sales of stone fruits in Hungary. The number of studied population were 95 capita, the number of filled out and evaluated questionnaires was 70. By the composition of the questions, both qualitative and quantitative methods have been used. The answers received were indicative and informative, however, proved to be inadequate to make final conclusions. The questionnaire, in addition to calibrating questions, intended to survey the knowledge of farmers in relation to the topics below:

$\square$ surveying the climate change related knowledge, knowledge on protection and prevention and conditions for application (financial, professional),

$\square$ sources of information, type of information (meteorological data required for protection, new protective technological elements, techniques of protection, technological solutions advancing damage mitigation),

$\square$ frequency and type of damage (exposition), possibilities for damage mitigation (types of funding, rate of own contribution),

$\square$ the role of human capital.

\section{Results and discussion}

Regarding the distribution between different age-categories of the people involved in the research work, a relative high homogeneity could be observed. The average age of the involved people was 44.14 years, the mean was 45 years. The value of average age and the median was near to each other. So the distribution of agecategories showed normal distribution. The value of standard deviation was low (St. Dev = 11.7), too (Figure 1).

The sex distribution of involved people reflects the national and county conditions as well. As much as $85.7 \%$ of the involved people are men (national rate: $86 \%$ ), while only $14.3 \%$ are women (national rate: $14 \%)$. This fact lets us conclude that although farming is present in women's lives, still they lead farms rather rarely. In most of the cases, they are represented as assisting or employed labour in the production

All respondents had heard about climate change; however, they had various views on the definition itself (Figure 2). Based on the

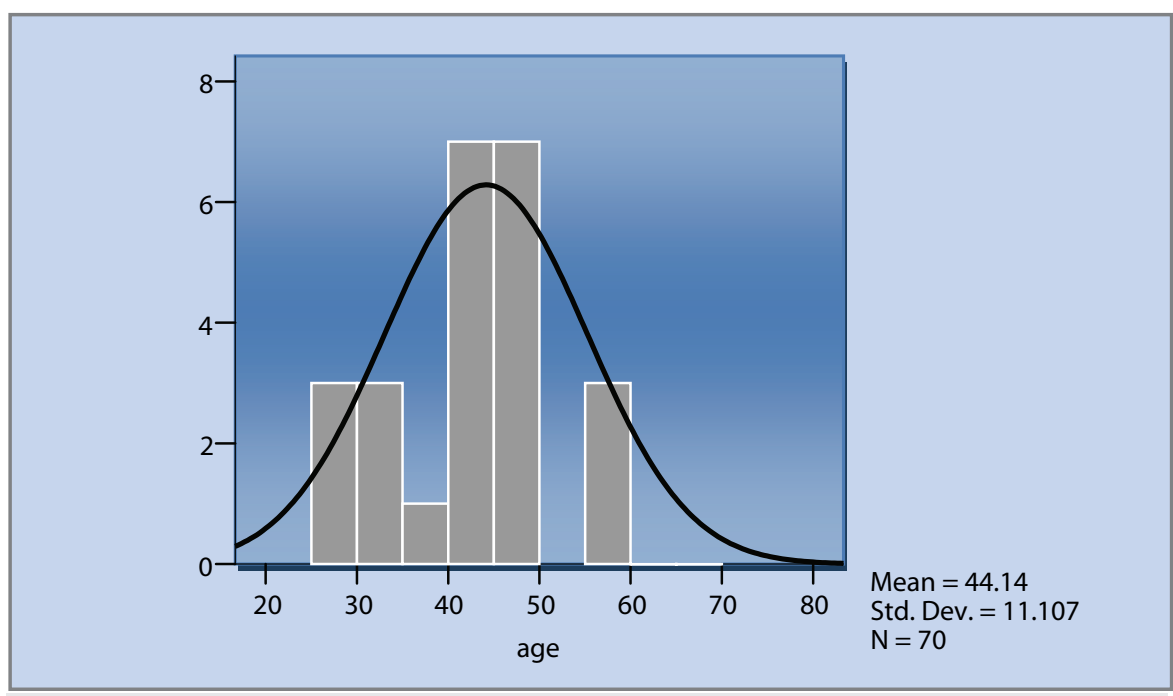

Figure 1 The distribution of involved answerers between different age-groups, regarding the frequency of the valid answers, 2009

Source: 0 the basis of empirical research; self-edited

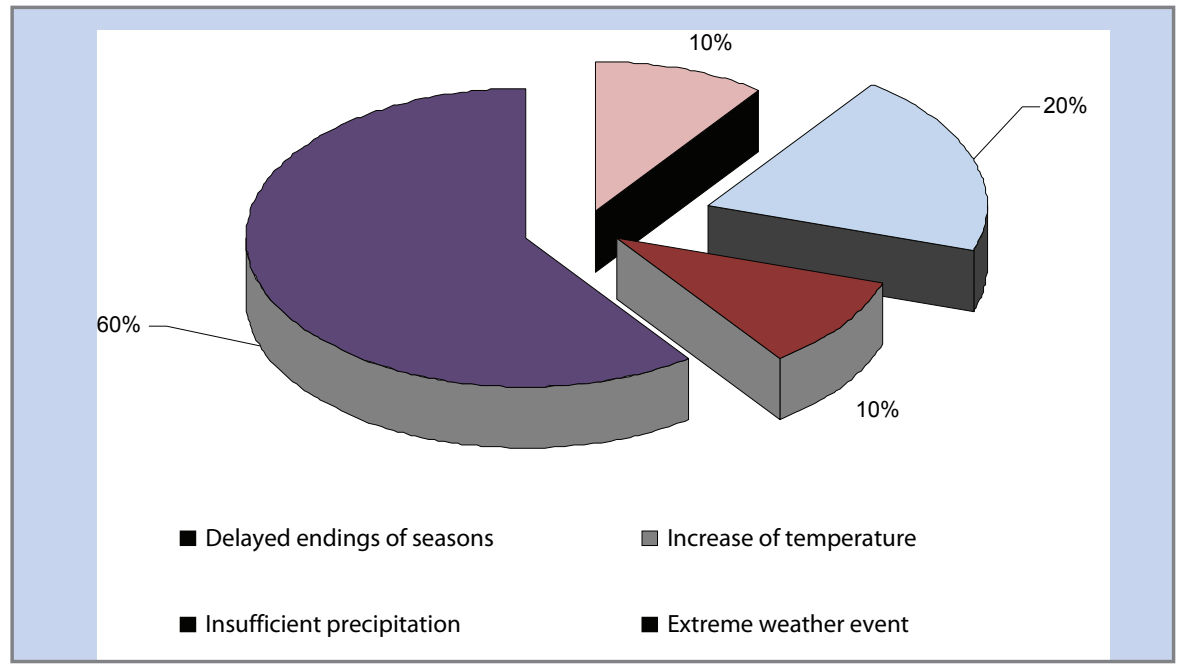

Figure 2 In your opinion, what does climate change mean?

$p=0.000, p \leq 0.05$

Source: On the basis of empirical research; self-edited 


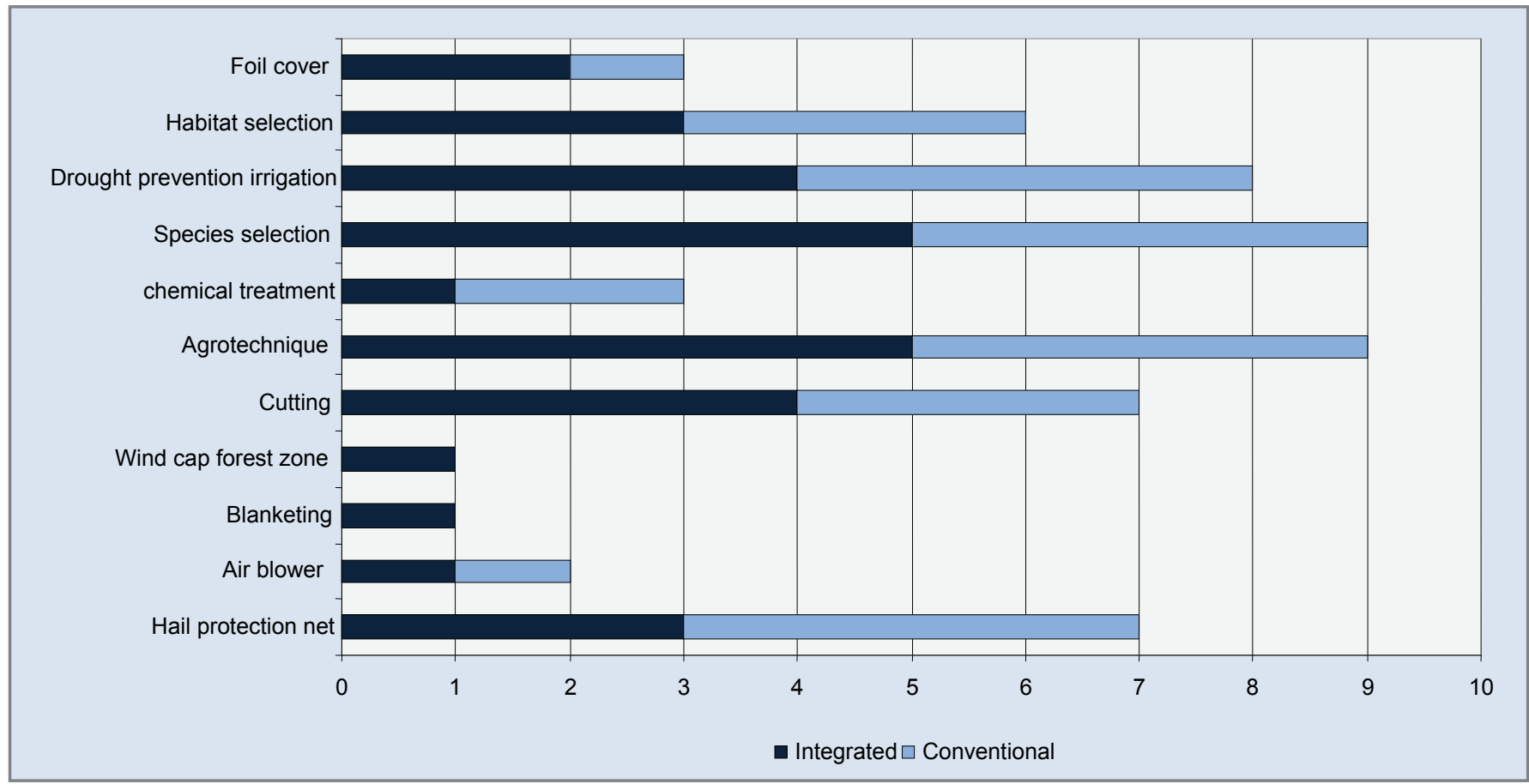

Figure 3 The share of protection technologies applied in preventing damage for various methods of cultivation, in function in $\%$ of the valid answers, 2010 $p=0.000, p \leq 0.05$

Source: On the basis of empirical research; self-editeded

answers, it is indicated that climate change was associated with extreme weather events having the most intensive direct influence on them or, to be more precise, on production. Regarding damage impacting them, drought and sunscald was mentioned the most frequently. This can be originated by the fact that the majority of respondents are hit by both drought and sunscald at several occasions each year. Hail-storm is experienced once in every 2 or 3 years whereas wind damage and storm damage occur less frequently than 2-3 years. This is likely to be the reason why these are mentioned less frequently when questioned about damage, however it is

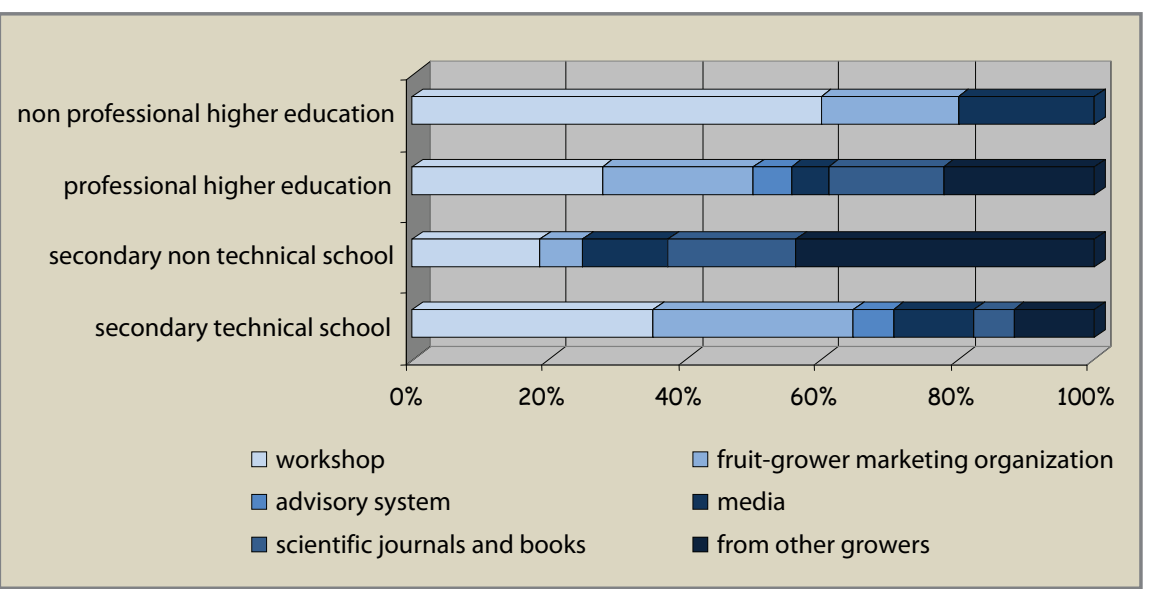

Figure 4 Correlation between educational level and information of variety use, in the distribution in \% of valid answers, 2009

Source: 0 n the basis of empirical research; self-edited an important finding that all respondents were hit by some kind of damage in the past 5 years. Following this, their affection for climate change is very high (Nagyné et al., 2011).

Regarding the technique of protection, in addition to the distribution of the given possibilities, the frequency of each category mentioned is also worth of studying (Figure 3). Here, conventional technological elements gained predominance in both categories of cultivation (70 percent of the respondents pursue integrated farming whereas $30 \%$ applies conventional technologies. At present, no biofarms are included in the sample). The share of fruit species can be relevant at correlation tests at present, however, taking the relatively low number of samples and the fact that this research is still being carried out, this question was not analysed.

During our research work, we searched the correlation between educational level and information of variety use, there are frozen resistant. The combination of information source is constricted as a function of education level (Figure 3). The advisory system is represented by a very low value. This fact calls the attention to the lack of advisory system in the horticultural sector.

But it is very important that between the educational level of growers and the usefulness of information there were no statistical correlation $(p=0.33)$. In the case of information utilization, the results of correlation analyses were the same $(p=0.57)$. Based on these correlation analyses, there is no statistical correlation between the age of the farmers and the factors affecting variety use $(p=0.22)$ neither as a function of the number of workers, the ratio of income from fruit production $(p=0.28)$, nor the time spent with farming so far $(p=0.21)$. Causes of lack of modern species in Hungary were also studied. Neither using of modern species $(p=0.64)$ nor causes of using of them $(p=0.61)$ were affected by education level (Nagyné et al., 2012).

Our results were not compared with other studies, because the studied population was quite unique. 


\section{Conclusion}

The results can greatly contribute to the elaboration of climate change related adaptation technologies for the sector as well as to foresee the success of implementation in practice. The results of this survey can primarily advance a more active contribution of farmers regarding the prevention and mitigation of production damages occurring in relation to the climate change. To this, processing of the entire questionnaire following the closure of research and explaining certain sections proved to be problematic and controversial. The way and type of source of information obtained from fruit farmers becoming capable of mitigating and preventing the above mentioned weather-caused damages can also be a subject to further studies.

Our results pointed out the Hungarian scientific establishment [Alvincz and Varga, 2000): Situation of family farms and possibilities for the improvement of their competitiveness; Kaproncai (2005): Characterisation of farmers' adaptability - The answers of farmers to actual questions; Alvincz (2001): The income-situation of agriculture and the affecting factors; The taxing of the incomes of individual agricultural producers] as the spread of marketable technologies are hindered by the low educational level and agronomic knowledge of farmers is false. We found that production experience is the strength of Hungarian growers to compensate their incomplete information. Only 2.9 percent of growers answered that the information source was satisfactory and suitable. Nearly 30 percent of growers gave the answer that the information sources were not useful and suitable. Based on the results of the correlation analyses, the answers given are proportionate among the educational levels of the respondents, therefore, the educational level does not determine the variety use of farms, neither as a function of the number of workers, the ratio of income from fruit production, nor the time spent with farming so far. Consequently, the lack of modern frost resistant species is due to the lack of capital and information.

This study gives a review on the responses received on topics regarding the concept of climate change and the frequency of damage occurrences as well as to the direct exposition of farmers to the negative impacts of climate change.

\section{References}

ALVINCZ, J. 2001. A mezőgazdaság jövedelemhelyzete és az arra ható tényezők. Budapest : Agrárgazdasági Kutató és Informatikai Intézet, 2001, no. 7, p. 7-11. ISSN 14182122.

ALVINCZ, J. - VARGA, T. 2000. A családi gazdaságok helyzete, versenyképességük javításának lehetőségei. In Agrárgazdasági Kutató és Informatikai Intézet, 2000, no. 15, p. 86. ISSN 14182122.

BABBIE, E. 2001. A társadalomtudományi kutatás gyakorlata. Budapest : Balassi Kiadó, 2001. p. 564. ISBN 978-963-506-764-0.

GLOVER, J. D. - REGANOLD, J. P. - ANDREWS, P. K. 2000. Systematic method for rating soil quality of conventional, organic, and integrated apple orchards in Washington State. In Agr. Ecosyst. Environ, 2000, no. 80, p. 29-45. ISSN 0167-8809.

HARNOS, ZS. - CSETE, L. 2008. Klímaváltozás: környezet - kockázat - társadalom. Budapest : Szaktudás Kiadó Ház, 2008. 34 p. ISBN 978-963-9736-87-0.

KAPRONCZAI, I. 2005. A mezőgazdasági termelők alkalmazkodóképességének jellemzői (Gazdálkodói válaszok időszerű kérdésekre). Agrárgazdasági Kutató és Informatikai Intézet. In Agrárgazdasági Tanulmányok, 2005, no. 6, p. 89. ISSN 1418-2122.

NAGYNÉ, D. D. - NYÉKI, J. - SOLTÉSZ, M. - SZABÓ, Z. 2012. The Role of Human Factor in the Innovation of Apricot Production - Empirical Study in a Disadvantage Area of East-Central European Country. In International Journal of Horticultural Science AGROINFORM Publishing House, 2012, no. 2, p. 131-135.

NAGYNÉ, D. D. - NYÉKI, J. - SZABÓ, Z. - SOLTÉSZ, M. 2011. Prevention and protection technologies - How do the growers get ready for climate change? In International Journal of Horticultural Science AGROINFORM Publishing House, 2011, p. 4-5. ISSN 1585-0404.

REGANOLD, J. P. - GLOVER, J. D. - ANDREWS, P. K. - HINMAN, H. R. 2001. Sustainability of three apple production systems. In Nature, 2001, no. 410, p. 926-929. ISSN16070658.

SANSAVINI, S. 1990. Integrated fruit growing in Europe. In HortScience, 1990, no. 25, p. 842-846. ISSN 0018-5345.

SOLTÉSZ, M. - NYÉKI, J. - SZABÓ, Z. 2007. Klímaváltozáshoz alkalmazkodó hazai kertgazdaság. In: Csete, L. - Jolánkai, M. - Láng, I. (ed): A globális klímaváltozás: hazai hatások és válaszok. Budapest : Szaktudás Kiadó Ház., 2007, 53 p. ISBN 9639736177.

SZIRMAI, V. 2009. Az éghajlatváltozás lehetséges térbeli társadalmi hatásai, a magyar társadalom klímatudatossága, sérülékenysége, alkalmazkodása. Discussion paper. http://www.nfft.hu/dynamic/Az_eghajlatvaltozas_tarsadalmi_hatasai_ klimatudatossag.pdf.

WEIBEL, F. P. - HÄSELI, A. - SCHMID, 0. - WILLER, H. 2004. Present status of organic fruit growing in europe. In Acta hort., 2004, no. 638, p. 375-385. ISSN 1231-0948.

WERNER, M. R. 1997. Soil quality characteristics during conversion to organic orchard management. In Appl. Soil ecol., 1997, no. 5, p. 151-167. ISSN 0929-1393.

\section{Contact address:}

Demeter Dóra, Károly Róbert University College, Mátrai út. 36, H-3200, Gyöngyös, Hungary, e-mail: demeterd@karolyrobert.hu 